\title{
Can parents' profession influence the attitude and competency among the first year medical students?
}

\author{
Kumar, S.N.S. ${ }^{1}$, Dutt, A.R. ${ }^{2}$, Hemraj, S.K. ${ }^{3}$, Shet, U.B. ${ }^{4}$, D S'ouza, N.D.R. ${ }^{5}$
}

\begin{abstract}
Introduction: The aspiration and career selection of students depends on the family atmosphere that includes parents' profession. Children of doctors are more influenced by their parents in selecting the medical field. Yet, every year many students whose parents are from other professions also enroll in medical college. Students with humanitarian touch, service oriented minds aiming towards global health care should opt for this service. Awareness about this profession would certainly help to remove their misconceptions and achieve their aims. This study is aimed at finding out the differences in attitude and awareness about this profession between children of doctors and non-doctors.
\end{abstract}

Methods: A questionnaire was administered to all students admitted to first year MBBS course. Content, construct validity and test retest reliability were applied to a questionnaire that was developed by the investigators after consulting the experts in the field. Responses were compiled and statistically analysed. Reliability coefficient for each question was calculated using Cronbach's alpha score. The data was analysed for normal distribution and parametric results were reported.

Results: The results revealed that motivation for selecting this profession seems to be less for social service and more for financial gains $(75 \%)$ in both groups. $50 \%$ of doctor's children were unaware of the syllabus of first MBBS and $55.6 \%$ of non-doctor's children had the same opinion. High percentages of the entire study group were unaware of the intricacies of learning medicine.

Conclusion: Children of doctors and non-doctors had similar attitude towards medical education.

Key words: Doctors, Non-doctors, Awareness, Medical training.

\section{Introduction}

The aspiration and career selection of students depend on the family atmosphere that includes parents' profession.

\footnotetext{
${ }^{1}$ Professor and Head, Department of Physiology, KVG Medical College and Hospital, Sullia, Karnataka, India.

${ }^{2}$ Professor and Head, Department of Physiology, Yenepoya Medical College, Deralakatte, Mangalore.

${ }^{3}$ Assistant Professor, Department of Radiology, MVJ Medical College, Hoskote, Bangalore.

${ }^{4}$ Professor and Head, Department of Physiology, Kanachur Institute of Medical Sciences, Deralakatte Mangalore.

${ }^{5}$ Lecturer, Department of Community Medicine, Yenepoya Medical College, Deralakatte, Mangalore.

Corresponding Author:

Satish Kumar N.S.

Professor and Head, Department of Physiology, KVG Medical College and Hospital, Sullia, Karnataka, India, PIN 574239.

E-mail: neriyana.s@gmail.com
}

Children of doctors are motivated early in life by observing their parents. It is also the desire of many doctors to see their wards continue to serve the society in the same profession. It is presumed that the children of doctors are better informed about the profession.

A study at South Carolina by Lentz has mentioned that $14 \%$ of medical students are children of doctors (Lentz, 1989). US study has found demographics of medical students (Carlisle, 1998). 69.3\% of fathers and $48.7 \%$ of mothers were professionals or high-level managers and $15.6 \%$ students had a physician parent (Dhalla et al., 2002).

The way the future doctors treat their patients depend on the skills and professionalism taught during their medical training (Klein et al., 2003; Hilton, 2005). Proper undergraduate

DOI: http://doi.org/10.4038/seajme.v12i2.51

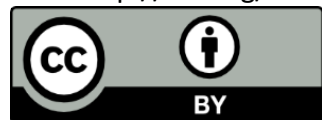

SEAJME. This is an Open Access article distributed under the terms of the Creative Commons Attribution License (http://creativecommons.org/licenses/by/4.0/), which permits unrestricted use, distribution, and reproduction in any medium, provided the original author and source are credited. 
medical training holds the key in providing universal healthcare for the humanity (Cruess, 2000).

The Royal College of Physicians of London's Working Party (2005) has stated that doctors should possess the values of humanity, commitment to the profession, benevolence compassion and consideration to the patients and should be able to work in a team. These qualities can build a good doctor-patient relationship.

A meta analysis mentions that the medical institutions must take up a greater responsibility in imparting professionalism among the future doctors (Cohen, 2006). This requires a proper curriculum design (Rubin, 2009), student selection (Knights, 2006), teaching-learning methods (Baernstein, 2003), role models (Kenny, 2003) and proper assessment of their professionalism (Jha, 2007).

Students selecting the medical career largely depend on the perceived returns from the profession. Children are more likely to get impressed by the parents' profession than getting attracted to other field. The social status and financial status of the parents also determine the selection of specialty (Dhalla et al., 2002).

It has been shown by previous studies that those who have a better pre existing knowledge about this course would cope well with this rigorous training (Zipp, 2010). Such students will be more oriented, receptive and develop the taught skills (Wheeler, 2015). This can avoid the misconceptions and initial fear about the medical course. There can always be an improvement in teaching learning process by understanding their initial perceptions. The changes in the training process can be planned after feed backs from the students.

Questionnaire based study is the most popular and widely accepted method of any evaluation system. Feedback taken will help the teachers and students in their self evaluation (Hamid, 2010). Responses received by the students' ratings can be utilized effectively to improvise the course, and to enhance their interest in the subject so that effective medical training can be imparted (Lata, 2008). We sought to find out the attitude and pre existing knowledge of the children of doctors and non-doctors selecting medical profession.

\section{Objectives}

To ascertain the attitudes and pre existing knowledge regarding medical curriculum among the children of doctors and non-doctors selecting medical profession.

\section{Methods}

Ninety one students of a fresh batch of a private university medical college in Karnataka state, India, who had just joined for their first year medical course, were included in this cross-sectional study. Before framing the questions, the need for the study was discussed with the teaching community and their opinions were considered.

Questionnaire items were developed after consulting the heads of the preclinical departments and validated appropriately. This is in accordance with the Dundee Ready Educational Environment Measure (DREEM) developed at Dundee University is considered as the most preferred method of collecting information of medical students' perceptions of the medical training (Roff, 2005). It has been validated as a universal diagnostic inventory for assessing the perceptions of undergraduate medical students in different institutions worldwide, with no cultural limitations.

The respondents were asked to read each statement clearly before responding. The responses were graded from most appropriate to least appropriate. The questions dealt were pertaining to: reason for selecting medical profession, curriculum content, learning methods, awareness of personal safety and patient examination. Ethical approval was sought and obtained from ethics committee of the Institute.

The reliability coefficient for each question was calculated using Cronbach's alpha score. Cronbach's alpha for the totality of items was 0.81 , which indicates high internal consistency.

Cronbach's alpha values for reason for selecting medical profession, curriculum content, learning methods (experimenting on self, cadaver and human fluids), awareness of personal safety and patient examination were $1,0.84,0.67,0.88,0.80,0.74,0.74$ and 0.64 respectively.

The objective of this study was explained and proper instructions were given to the students 
before responding to the questions. The questionnaire was administered during the students' orientation week. The responses were obtained from only those who consented. (Response rate $=98 \%$ )

\section{Statistics}

SPSS version 16 and Microsoft excel 2007 were used for data analysis. The data was analysed for normal distribution and parametric results were reported. The results were reported as percentages.

\section{Results}

Of the ninety students who were administered the questionnaire, one student was absent and one student's response was incomplete, hence excluded from analysis. The mean age of the study group was 19.5 years $(S D=1.4)$ ranges from 18 to 21 years. As shown in Table 1 , the group was divided based on profession of the parents into group A (at least one parent is a doctor) and group $B$ (parents in other profession). The questions are tabulated in table 2 and responses summarized in Figures $1-2$ and Tables 3-4.

Table 1: Composition of the study group $(n=89)$

\begin{tabular}{lcc}
\hline \multirow{2}{*}{ Parents' Profession } & \multicolumn{2}{c}{ Number of Students } \\
\cline { 2 - 3 } & Group A & Group B \\
\hline Doctors & 34 & - \\
Business & - & 26 \\
Engineer and Private & - & 17 \\
Teacher & - & 7 \\
Government Employee & - & 4 \\
Farmer & - & 1 \\
\hline
\end{tabular}

Table 2: Options of questionnaire

\begin{tabular}{|c|c|c|c|c|}
\hline \multirow{2}{*}{ Questions } & \multicolumn{4}{|c|}{ Options } \\
\hline & $\mathbf{a}$ & b & C & d \\
\hline Selecting the profession & $\begin{array}{l}\text { Parents' } \\
\text { Desire }\end{array}$ & Social service & $\begin{array}{l}\text { Respect from } \\
\text { Society }\end{array}$ & Money \\
\hline $\begin{array}{l}\text { Medical syllabus- continuation } \\
\text { of plus } 2\end{array}$ & strongly agree & disagree & agree & don't know \\
\hline Experiments on self & strongly agree & disagree & agree & don't know \\
\hline Experiments on cadavers & strongly agree & disagree & agree & don't know \\
\hline Examining patients & strongly agree & disagree & agree & don't know \\
\hline Experiments with human fluids & strongly agree & disagree & agree & don't know \\
\hline $\begin{array}{l}\text { Learning medicine by } \\
\text { 1)Theory Lectures } \\
\text { 2)Practical Demonstration } \\
\text { 3)Examining Patients } \\
\text { 4)Computer assisted Learning } \\
\text { 5)Interactive learning } \\
\text { 6)Library assisted learning }\end{array}$ & $\begin{array}{l}\text { Theory } \\
\text { Lectures } \\
\text { and Practical } \\
\text { Demonstration }\end{array}$ & $\begin{array}{l}\text { Practical } \\
\text { Demonstration } \\
\text { and Examining } \\
\text { Patients }\end{array}$ & $\begin{array}{l}\text { Theory Lectures, } \\
\text { Practical } \\
\text { Demonstration, } \\
\text { Examining } \\
\text { Patients and } \\
\text { Interactive } \\
\text { learning }\end{array}$ & $\begin{array}{l}\text { Theory Lectures, } \\
\text { Practical } \\
\text { Demonstration, } \\
\text { Examining } \\
\text { Patients, Computer } \\
\text { assisted Learning } \\
\text { and Library } \\
\text { assisted learning }\end{array}$ \\
\hline
\end{tabular}

Table 3: Responses of children of Doctors

\begin{tabular}{cccccccc}
\hline & $\begin{array}{c}\text { Reason for } \\
\text { selecting } \\
\text { the }\end{array}$ & $\begin{array}{c}\text { Medical } \\
\text { syllabus- } \\
\text { continuation } \\
\text { profession }\end{array}$ & $\begin{array}{c}\text { Experiments } \\
\text { on self }\end{array}$ & $\begin{array}{c}\text { Experiments } \\
\text { on cadavers }\end{array}$ & $\begin{array}{c}\text { Examining } \\
\text { patients }\end{array}$ & $\begin{array}{c}\text { Experiments } \\
\text { with human } \\
\text { fluids }\end{array}$ & $\begin{array}{c}\text { Learning } \\
\text { Modes }\end{array}$ \\
\hline a & 25 & 11 & 14 & 5 & 7 & 5 & 6 \\
b & 0 & 4 & 16 & 0 & 10 & 13 & 0 \\
c & 5 & 56 & 24 & 10 & 11 & 18 & 65 \\
d & 69 & 29 & 46 & 85 & 72 & 64 & 29 \\
\hline
\end{tabular}




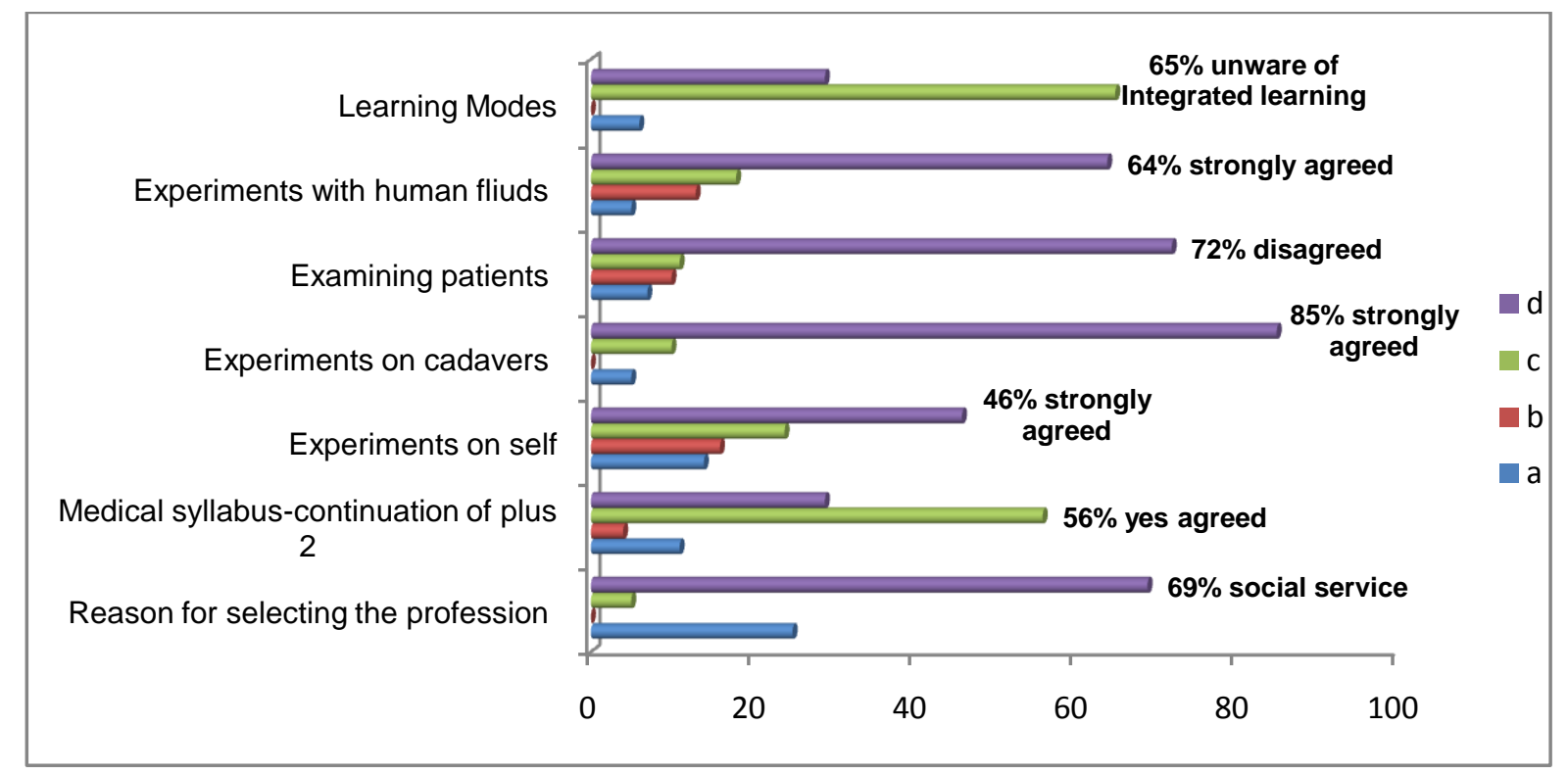

Figure 1: Responses of children of Doctors

Table 4: Responses of the children of Non-Doctors

\begin{tabular}{cccccccc}
\hline & $\begin{array}{c}\text { Reason for } \\
\text { selecting } \\
\text { the }\end{array}$ & $\begin{array}{c}\text { Medical } \\
\text { syllabus- } \\
\text { continuation } \\
\text { of plus 2 }\end{array}$ & $\begin{array}{c}\text { Experiments } \\
\text { on self }\end{array}$ & $\begin{array}{c}\text { Experiments } \\
\text { on cadavers }\end{array}$ & $\begin{array}{c}\text { Examining } \\
\text { patients }\end{array}$ & $\begin{array}{c}\text { Experiments } \\
\text { with human } \\
\text { fluids }\end{array}$ & $\begin{array}{c}\text { Learning } \\
\text { Modes }\end{array}$ \\
\hline p & 9 & 9 & 12 & 9 & 9 & 3 & 3 \\
b & 0 & 12 & 26 & 0 & 12 & 6 & 0 \\
c & 6 & 47 & 20 & 12 & 9 & 24 & 62 \\
d & 85 & 32 & 42 & 79 & 70 & 67 & 35 \\
\hline
\end{tabular}

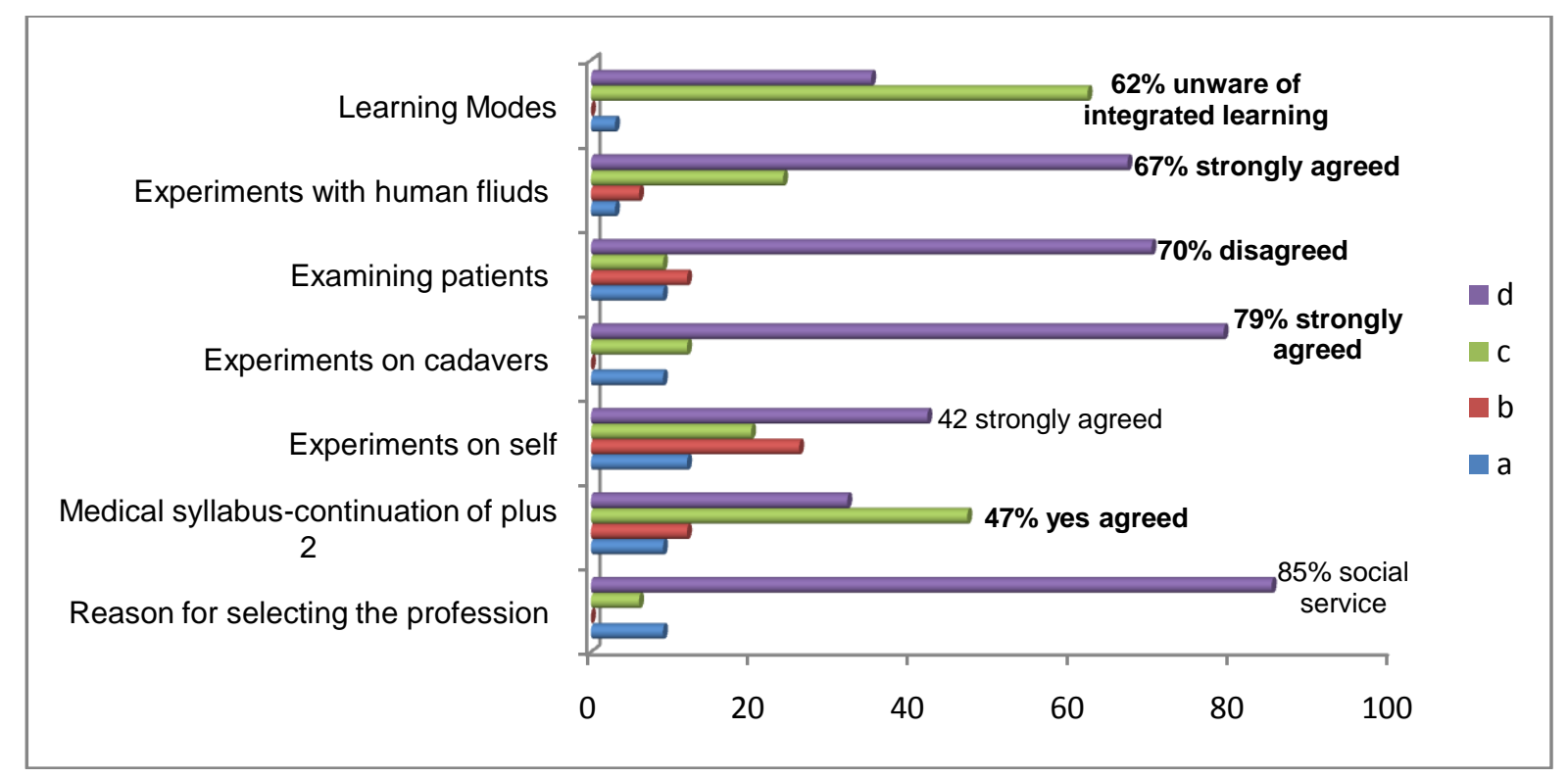

Figure 2: Responses of the children of Non-Doctors 


\section{Discussion}

This study was aimed at finding out the students' attitude, motivation behind joining the medical course, their knowledge of medical curriculum, mode of learning, precautions involved in examining the patients among the students who have doctor as parents (group A) and others (group B). There appears to be a large change in the attitude and pre existing knowledge about the medical profession among the newer generation who select this course.

The motivation for selecting this profession seems to be parents' desire $(19.1 \%)$, respect from society $(5.6 \%)$ and financial gains (75.3\%). $75 \%$ of group A and $75.3 \%$ of group $B$ had the later opinion. Social service was not the reason behind choosing this course. Motivation, commitment, personality, attitudes and traits are considered beneficial at medical school for lifelong learning rather than financial gains (McManus et al., 2005).

The ideology behind selecting medical profession as a carrier has changed drastically over a decade (Ferrinho et al., 2010). Even though medical students of African countries have shown high level of commitment to social service (Ferrinho et al., 2010) their counterparts in Guinea-Bissau still have very high salary expectations.

In the selection process for training medical doctors, a set of criteria have been listed which comprises of communication skills, empathy, flexibility, decision making, honesty, reflective manner, insight about stress management, self management, illness and medicine and global performance. These attributes were graded at the time of interview and selected based on their best performance (Kaiser, 2007).

Majority of the students are of the opinion that the first year medical curriculum is not the continuation of the pre-university syllabus. High percentages of the students are unaware of the fact that experimenting on self and on cadavers is a mode of learning medicine. All the students think that patient examination is not a part of first year medical syllabus. Knowledge of experiments with human fluids is low in all these groups.

The mode of learning medical subjects preferred by majority of the students is,

1) By Theory lectures

2) Practical demonstration
3) Examining patients

4) Interactive learning

Less than $30 \%$ of the students are of the view that computer and library assisted learning should be a modality of medical education. Computer and internet usage for medical knowledge and research is increasing among undergraduate and postgraduates as they advance in their course (Unnikrishnan et al., 2008). Use of computer assisted medical education has got the advantage of demonstrating the procedures, understanding the physiological processes occurring in the human body and concept of evidence based learning (Sharma et al., 2006). Though it is presumed that children of doctors' are better informed about the medical profession than others, in this study it appears that both groups have similar perceptions.

\section{Conclusion}

The awareness about medical profession is similar in both students from doctors' family and non-doctors'. The requirements and qualities should be explained to the students before joining the course itself so that an effective medical training can be imparted.

\section{References}

Baernstein, A. \& Fryer-Edwards, K. (2003) Promoting reflection on professionalism: a comparison trial of educational interventions for medical students, Academic Medicine, 78, 7, pp. 742-747.

Carlisle, D.M., Gardner, J.E. \& Liu, H. (1998) The entry of underrepresented minority students into US medical schools: an evaluation of recent trends, American Journal of Public Health, 88, 9, pp. 1314-1318.

Cohen, J.J. (2006) Professionalism in medical education, an American perspective: from evidence to accountability, Medical Education, 40, 7, pp. 607-617.

Cruess, R.L., Cruess, S.R. \& Johnston, S.E. (2000) Professionalism and medicine's social contract, JBJS, 82, 8, pp. 1189-1194.

Dhalla, I.A., Kwong, J.C., Streiner, D.L., Baddour, R.E., Waddell, A.E. \& Johnson, I.L. (2002) Characteristics of first-year students in Canadian medical schools, Canadian Medical Association Journal, 166, 8, pp. 1029-1035.

Ferrinho, P., Fronteira, I., Sidat, M., da Sousa, F. \& Dussault, G. (2010) Profile and professional expectations of medical students in Mozambique: a longitudinal study, Human Resources for Health, 8, 1, pp. 21-25. 
Ferrinho, P., Fronteira, I., Sidat, M., Hipólito, F., Mercer, H. \& Dussault, G. (2010) Formação médica em Moçambique: realidade e expectativas, Revista Médica de Moçambique, 10 , pp. $52-58$.

Hamid, Y. \& Mahmood, S. (2010) Understanding constructive feedback: a commitment between teachers and students for academic and professional development, Journal of Pakistan Medical Association, 60, 3, pp. 224-227.

Hilton, S.R. \& Slotnick, H.B. (2005) Proto-professionalism: how professionalisation occurs across the continuum of medical education, Medical Education, 39, 1, pp. 58-65.

Jha, V., Bekker, H.L., Duffy, S.R. \& Roberts, T.E. (2007) A systematic review of studies assessing and facilitating attitudes towards professionalism in medicine, Medical Education, 41, 8, pp. 822-829.

Kaiser, F., Dewan, H.B. \& Mansoor, F. (2007) Selection of Medical Students Admission and Selection Policy, Rawal Medical Journal, 32, 2, pp. 193-196.

Kenny, N.P., Mann, K.V. \& Mac Leod, H. (2003) Role modeling in physicians' professional formation: reconsidering an essential but untapped educational strategy, Academic Medicine, 78, 12, pp. 1203-1210.

Klein, E.J., Jackson, J.C., Kratz, L., Marcuse, E.K., McPhillips, H.A., Shugerman, R.P., Watkins, S. \& Stapleton, F.B. (2003) Teaching professionalism to residents, Academic Medicine, 78, 1, pp. 26-34.

Knights, J.A. \& Kennedy, B.J. (2006) medical school selection. Medical school selection: screening for dysfunctional tendencies, Medical education, 40, 11, pp. 1058-1064.

Lata, H., Walia, L. \& Gupta, V. (2008) Student feedback on teaching and evaluation methodology in physiology, South East Asian Journal of Medical Education, 2, pp. 31-37.

Lentz, B.F. \& Laband, D.N. (1989) Why so many children of doctors become doctors: nepotism vs. human capital transfers, Journal of Human Resources, pp. 396-413.
McManus, I.C., Powis, D.A., Wakeford, R., Ferguson, E., James, D. \& Richards, P. (2005) Intellectual aptitude tests and A levels for selecting UK school leaver entrants for medical school, BMJ, 331, 7516, pp. 555-559.

Roff, S. (2005) The Dundee Ready Educational Environment Measure (DREEM)-a generic instrument for measuring students' perceptions of undergraduate health professions curricula, Medical Teacher, 27, 4, pp. 322-325.

Royal College of Physicians (2005) Doctors in society: Medical professionalism in a changing world, Report of a Working Party of the RCP. London: Royal College of Physicians, Lavenham Press Ltd, Great Britain.

Rubin, P. (2009) Tomorrow's Doctors: out-comes and standards for undergraduate medical education, London: General Medical Council.

Sharma, R., Verma, U., Sawhney, V., Arora, S. \& Kapoor, V. (2006) Trend of Internet use among medical students, JK Science, 8, 2, pp. 101102.

Unnikrishnan, B., Kulshrestha, V., Saraf, A., Agrahari, A.C., Prakash, S., Samantaray, L. \& Parida, A. (2008) Pattern of computer and internet use among medical students in Coastal South India, South East Asian Journal of Medical Education, 2, 2, pp. 18-25.

Wheeler, E. \& Arena, R. (2009) The impact of feeder school selectivity on predicting academic success in an allied health professional program, Journal of Allied Health, 38, 3, pp. 79-83.

Zipp, G.P., Ruscingno, G. \& Olson, V. (2010) Admission variables and academic success in the first year of the professional phase in a doctor of physical therapy program, Journal of Allied Health, 39, 3, pp. 138-142. 